\title{
Clinical utility of calf front hoof circumference and maternal intrapelvic area in predicting dystocia in 103 late gestation Holstein-Friesian heifers and cows
}

\begin{abstract}
The objective of this study was to determine the clinical utility of measuring calf front hoof circumference, maternal intrapelvic area, and selected morphometric values in predicting dystocia in dairy cattle. An observational study using a convenience sample of 103 lategestation Holstein-Friesian heifers and cows was performed. Intrapelvic height and width of the dam were measured using a pelvimeter, and the intrapelvic area was calculated. Calf front hoof circumference and birth weight were also measured. Data were analyzed using Spearman's correlation coefficient $\left(r_{s}\right)$, Mann-Whitney $U$ test, and binary or ordered logistic regression; $\mathrm{P}<0.05$ was significant. The calving difficulty score $(1-5)$ was greater in heifers (median, 3.0) than in cows (median, 1.0). Median intrapelvic area immediately before parturition was smaller in heifers $\left(268 \mathrm{~cm}^{2}\right)$ than in cows $\left(332 \mathrm{~cm}^{2}\right)$, whereas front hoof circumference and birth weight of the calf were similar in both groups. The calving difficulty score was positively associated with calf birth weight in heifers $\left(r_{s}=0.39\right)$ and cows $\left(r_{s}=0.24\right)$. Binary logistic regression using both dam and calf data indicated that the ratio of front hoof circumference of the calf to the maternal intrapelvic area provided the best predictor of dystocia (calving difficulty score $=4$ or 5), with sensitivity $=0.50$ and specificity $=0.93$ at the optimal cutpoint for the ratio $\left(>0.068 \mathrm{~cm} / \mathrm{cm}^{2}\right)$. Determining the ratio of calf front hoof circumference to maternal intrapelvic area has clinical utility in predicting the calving difficulty score in Holstein-Friesian cattle.
\end{abstract}

Keyword: Intrapelvic area; Dystocia; Calving difficulty; Pelvimeter; Hoof circumference 